\title{
Proses Dan Kendala Penyidik Polresta Jambi Dalam Mengungkap Tindak Pidana Penipuan Melalui Media Elektronik
}

\author{
Nelli Herlina, Dessy Rakhmawati \\ Fakultas Hukum, Universitas Jambi, Indonesia
}

\begin{abstract}
ABSTRAK
Proses penyidikan tindak pidana penipuan menggunakan media elektronik tidak ada bedanya dengan proses penyidikan Tindak pidana biasa, namun dalam proses penyidikan tindak pidana penipuan melalui media elektronik pihak penyidik Polresta Jambi mengalami hambatan dan kendala. Hanya sedikit kasus yang dapat terselesaikan karena adanya kendala yang sulit dipecahkan untuk menemukan tersangka yang melakukan tindak pidana penipuan melalui media elektronik salah satu sebabnya lemahnya personil penyidik dalam ilmu Informasi dan Teknologi, sulitnya mencari identitas tersangka, karena biasanya tersangka menggunakan identitas palsu. Oleh sebab itu penulis tertarik untuk melakukan penelitian menganai proses dan kendala Penyidikan tindak pidana Peniluan melalui media ektronik di Polresta Jambi.
\end{abstract}

Kata Kunci: Proses Penyidikan, kendala penyidikan, penipuan melalu media elektronik

\section{PENDAHULUAN}

Perkembangan teknologi informasi memberikan dampak positif maupun negatif. Pemanfaatan ternologi disatu pihak memberikan kontribusi yang baik untuk peningkatan kesejahteraan dan peradaban manusia, namun dipihak lain perkembangan yang begitu pesat juga memberikan dampak negatife, dengan perkembangan teknologi yang begitu pesat ternyata kejahatanpun berkembang begitu pesat, kemajuan teknologi tersebut di manfaatkan oleh beberapa orang untuk malakukan perbuatan yang dilarang. ${ }^{1}$

Dampak posifif dalam perkembangan informasi dan teknologi ialah kita dengan mudah mendapatkan berbagai informasi, memudahkan kita dalam berinterkasi antara yang satu dengan yang lain, salah satu contohnya ketika ingin membeli seseuatu barang konsumen tidak harus ke toko atau pun kepasar konsumen bisa membeli barang hanya dengan memanfaatkan aplikasi yang ada di handphone, sehinggga tidak dapat kita pungkiri bahwa dengan perkembangan ternologi pada saat ini kita bisa dengan mudah untuk mendapatkan informasi mengenai sesuatu hal dan memudahkan untuk melakukan barbagai hal termasuk transaki pembelian barang. Sedangkan Dampak negatif dari perkembangan informasi dan transaksi elektronik yaitu terjadi kejahatan-kejatan yang dilakukan di dunia maya jual beli online, di sini antara konsumen dan penjual tidak harus bertemu mereka bisa

${ }^{1}$ Adami Chazawi, Tindak Pidana Informasi \& Transaksi Elektoik, Cet. 1, Media nusa Creative, Malang, 2015, hlm.2. 
menggunakan kecanggihan teknologi untuk melakukan transasksi jual beli, namun tidak sedikit yang menyalah gunakan kemajuan teknologi ini, misalnya dalam jual beli barang menggunakan facebook, dimana sering terjadi penipuan dan untuk mengungkap identitas sipenipu agak sulit karena biasanya pelaku tindak pidana menggukana akun palsu data-data yang palsu, kemudian sering juga terjadi penipuan yang diawal dengan berkenalan di media sosial, berkenalan melalui facebook kemudian dijanjikan akan di nikahi atau di berikan barang dan meminta korban untuk mentransper uang ke pelaku, kemudian korban mentrasper uang ternyata pelaku tidak menepati janji. Hal ini merupakan salah satu contoh dengan kemajuan ternologi yang ada pada saat ini ternyata tidak hanya memberikan dampak positif tetapi juga dampak negatif..

Berkenaan dengan hal tersebut hukum pidana harus mengikuti perkembangan zaman, dimana diketahui bahwa Kitab Undang-Undang Hukum Pidana merupakan peninggalan dari Belanda yang, berlaku di Indonesia tahun 1918, dulu namanya Wetboek Van Strafrech (Wvs), dari tahun 1918 ke tahun 2020 sudah hampir 1 abad kita masih menggunakan produk peninggalan Belanda tentu banyak perbuatan yang tidak diatur walaupun di atur tetapi tidak begitu komples. Sementara itu manusia semakin hari sekamin berkembang begitu juga dengan kejatan semakin berkembang banyak atur yang di ada ada pengaturannya di dalam Kitab undangUndang Hukum Pidana.

Oleh karena itu tanggal 21 April 2008 telah diundangkan Undang-Undang No. 11 Tahun 2008 sebagai mana yang sudah di perbaharui dengan Undang-Undang No. 19 Tahun 2016 Tentang Informasi dan Transaksi Elektronik. Terdapat 9 Pasal yang di atur mengenai perbuatan yang di larang di dalam Undang-Undang ITE, mulai Pasal 27 sampai Pasal 35. Namun dalam tulisan ini lebih memfokuskan Pasal 28 ayat (1) yang menyangakan "setiap orang dengan sengaja tanpa hak menyebarkan berita bohong dan menyesatkan yang mengakibatkan kerugian pada konsumen melalui transaksi elektronik". Dan bentuk sanksi dari perbuatannya diatur dalam Pasal 45 ayat (2) "setiap oarang yang memenuhi sebagaimana dimaksud dalam Pasal 28 ayat (1) atau ayat (2) dipidana dengan pidana penjara paling lama 6 tahun dan/atau denda paling banyak Rp.1000.000.000,00 (satu miliar rupiah)". Undang-Undang ITE merupaka perbuatan pidana khusus, walaupun sebenarnya perbuatan yang di larang di dalam Undang-Undang ITE juga di atur di dalam KUHP seperti penipuan juga di atur didalam KUHP, ia menjadi khus karena cara melakukannya melalui elektronik. Perbuatan yang menyerang kepentingan hukum orang pribadi, yang dilakukan dengan memanfaatkan sarana teknologi transaksi elektronik baik itu facebook, instagram, twiter ini merupakan sisi negatif darai kemajuan tekologi. ${ }^{2}$

Perbuatan penipuan itu selalu ada, sama hal nya dengan kejahatan pada dasarnya kejahatan tidak dapat di hapuskan, namun setidaknya harus bisa di minimalkan. Di zaman moderen seperti sekarang banyak terjadi penipuan yang

\footnotetext{
${ }^{2}$ Adami Chazawi, Op. Cit., hlm.3.
} 
dilakukan melalui media elektronik, Padahal apaun pun alasannya dan bagaimanapun sarananya perbutan penipuan merupakan perbuatan yang tercela, perbuatan yang tidak baik dan pada akhirnya merugikan orang lain. ${ }^{3}$ Misalnya penipuan dalam hal penjualan barang melalui akun facebook, instagram dan lain-lain, seringkali konsumen tertarik dengan melihat harga barang yang begitu murah yang di tawarkan di bandingkan dengan harga di pasaran, konsumen juga bisa melihat berbagi model pakaian, handpohe apapun barang yang di jual tanpa harus pergi ke toko tersebut, selain itu terkadang hal yang membuat seseorang membeli barang melalui media elektronik karena tidak ada waktu untuk ke pasar sehingga dengan perkembangan teknologi saat ini dapat mempermudah dalam pembelian barang, konsumen bisa dengan mudah berintraksi dengan penjual walaupun sedang berada di rumah, bahkan berda kota, mereka tetap bisa saling berinteraksi dengan kemajuan ternologi sekarang, namun ternayata banyak juga korban yang tertipu dalam melakukan pembelian barang melalui media elektronik.

Dari informasi penyidik Kepolisian Polresta Jambi di ketahui bahwa terdapat beberapa laporan menganai penipuan yang terjadi melalui media elektronik, di mana penyidik dalam menangani kasus ini terdapat beberapa kendala yaitu pihak penyidik Polresta Jambi sulit untuk menemukan identitas tersangkanya karena tersangka menggunakan akun palsu dalam berinteraksi dengan korban. Selain itu, dalam melakukan penyidikan pihak penyidik Polresta Jambi diberikan kewenangan untuk bekerja sama dengan lembaga lain, termasuk operasional telepon seluluer dan pihak bank demi mempermudah proses penyidikannya.

Penelitian di Polresta Jambi menunjukan bukti di mana masyarakat saat ini sudah banyak yang menggunakan kemajuan teknologi dalam melalukan transaksi. Namun demikian, mudahnya fasilitas teknologi tersebut menyebabkan banyak orang yang tidak bertanggung jawab dan melakukan kejahatan elektronik. Menyikapi hal tersebut, pihak Polresta Jambi harus mampu untuk menanggulangi tindak pidana yang dilakukan melalui ITE.

Tabel 1. Data jumlah tindak pidana penipuan media elektronik 3 tahun terakhir di Polresta Jambi (Terhitung s/d September 2019)

\begin{tabular}{cccc}
\hline No & Tahun & Jumlah Laporan & Jumlah Laporan yang Selesai Diproses \\
\hline 1. & 2017 & 4 & 3 \\
2. & 2018 & 7 & 4 \\
3. & 2019 & 14 & 7 \\
\hline & Jumlah & 25 & 14 \\
\hline
\end{tabular}

Sumber Dara: Polresta Jambi

\footnotetext{
${ }^{3}$ Abdul Wahid, Kejahatan Mayantara, PT Refika Aditama, Bandung, 2005, hlm. 30.
} 
Pada tabel di atas terdapat beberapa laporan yang tidak dapat terselesaikan pada tahun 2017 ada 4 laporan dan hanya 3 laopran yang terselesaikan, pada tahun 2018 ada 7 laporan dan hanya 4 laporan yang terselesaikan, pada tahun 2019 ada 14 laporan dan hanya 7 laporan yang terselesaikan, sehingga dapat di katakan bahwa dalam lima tahun terakhir ini ada 25 laporan yang masuk mengenai penipuan melalui media elektronik, namun hanya 14 laopran tersebut terselesaikan, hal ini dikarenakan adanya beberapa bukti dan unsur-unsur pada laporan tersebut yang membuat pihak penyidik tidak bisa melanjutkan tindakannya.

Data di atas menunjukkan banyaknya laporan yang tidak dapat terselesaikan oleh pihak penyidik Polres Jambi dikarenakan adanya beberapa problem dalam melakukan proses penyidikan terhadap Penipuan melalui media elektronik., sehingga penelitian akan memfokuskan pada proses dan kendala penyidikan dalam tindak pidana melalui media elektronika.

Dari apa yang diuraikan pada latar belakang masalah di atas, peneliti mengangkat permasalahan dengan rumusan:

1. Bagaimana Proses penyidikan penyidik Polresta Jambi dalam menangani tindak pidana penipuan melalui media elektronik?

2. Bagaimana kendala dan upaya penyidik Polresta Jambi dalam meanggulangani tindak pidana penipuan melalui media elektronik?

Penelitian ditujukan untuk menganalisa kendala penyidik Polresta Jambi dalam sulitnya menugkap pelaku tindak pidana penipuan yang dilakukan melalui media elektronik, selain itu tujuan dalam penelitian ini untuk memberikan sumbangan pemikiran untuk kedepannya dengan memperhatikan peraturan perundangan-undangan yang berhubungan dengan penelitian ini agar penyidik kedepannya dapat dengan mudah mengungkap tindak pidana penipuan yang dilakukan melalui media elektronik.

Urgensi dari penelitian ini bahwa hukum harus memberika keadilan, kepastian dan kemanfaatan, pentingganya mengungkap pelaku yang melakukan tindak pidana melalui media elektronik sangat penting dalam memberikan keadilan, kepastian dan kemanfaatan bagi masyarakat. mengingat perkembangan zaman saat ini semakin hari semakin pesat dan maju, ternyata kejahatanpun demikian berbagai cara dapat dilakukan seseorang dalam melakukan tindak pidana, salah satunya yaitu tindak pidana penipuan melalui media elekrtonik, yang mana pada saat ini penyidik masih mengalami kendala dalam menggungkap tindak pidana tersebut, sehingga perlu diketahui apa saja kendala penyidik dalam menggngkap tindak pidana penipuan melalui media elektronik.

\section{TINJAUAN PUSTAKA}

Telah ada beberapa penelitan terdahulu dahulu yang telah dilakukan, adapun yang mendekati penelitian yang saat ini sedang tim peneliti akan laksanakan yaitu 
penelitian yang di susun oleh Siti Aisah meneliti tentang Faktor-Faktor terjadinya tindak pidana penipuan melalui media elektronik (online) yang mana hasil dari penelitiannya yaitu bahawa salah satu faktor terjadinya penipuan melalui media elektronik (online) karena masyarakat mudah tergiur dan tertarik dengan murahnya harga barang yang di tawarkan di bandingkan dengan harga di pasaran sehingga sangat mudah untuk di manfaatkan pelaku penipuanselain itu faktor ekomoni juga merupakan faktor pendukung dari penyebab adanya tindak pidana penipuan tersebut, adanya himpitan gaya hidup yang berlebihan sehingga menjadian seseorang untuk melakukan apa saja demi sesuatu yang menreka inginkan berdasarkan kebutuhan hidup mereka. Sedangkan penelitian yang penulis teliti mengenai Proses dan kendala Penyidik Polresta Jambi dalam mengungkap tindak pidana penipuan melalui media elektronik karena biasanya si pelaku menggukana akun palsu yang mana semua identitasnya palsu

Penelitian yang dilakukan ini jauh berbeda dengan penelitian yang telah tim paparkan di atas yang mana dalam penelitian ini mengkaji proses dan kendala penyidik Polresta Jambi dalam megungkap tindak pidana penipuan yang di lakukan melalui media elektronik . berkaitan dengan hal tersebut penelitian yang dilakukan oleh tim peneliti berbeda dengan penelitan sebelumnya.

Menurut Hans Kelsen bahawa hukum adalah "sebuah kepatuhan masyarakat apakah orang-orang pada kenyataan berbuat menrut suatu cara untuk menghidari sanksi yang diancam oleh norma hukum atau bukan dan apakah sanksi tersebut benar-benar dilaksanakan bila syaratnya terpenuhi atau tidak terpeduhi." ${ }^{4}$ Teori ini adala teori yang mengkaji dan menganalisas tentang keberhasilan, kegagalan dan kendala apa yang mempengaruhinya dalam pelaksanaan dan penerapan hukum. ${ }^{5}$ Ada 5 (lima) Faktor yang harus di perhatikan dalam penegakan hukum menurut Soerjono Soekanto yaitu:

1. Undang-Undang

2. Penagak Hukum

3. Fasilitas

4. Masayarakat

5. Budaya. ${ }^{6}$

Apabila kelima faktor di atas dilaksanakn sebagaimana mestinya, maka tolak ukur berikutnya yang dapat dilakukan dalam efektifitas hukum adalah keberhasilan dan kegagalan. Dapat disimpulkan bahwa faktor yang banayak mempenggaruhi efektifitas suatu perundang-udangan adalah profesional dan optimal dalam pelaksanaan peran, wewenang dan fungsi bagi aparat penegak hukum, khususnay

\footnotetext{
${ }^{4}$ Hans Kelsen, Teori Umum Tentang Hukum dan Negara, Nusa Media, Bandung, 2006, hal.39.

${ }^{5}$ Ibid

${ }^{6}$ Soerjono Soekamto, Faktor-Faktor yang mempengaruhi Penagakan Hukum, PT.Raja Grafindo, Jakarta, 2018, Hal.8.
} 
Polisi dalam melakukan penyidikan terhadap tindak pidana penulipan yang di lakukan melalui media elektronik online.

Pada asasnya, melalui visi Kitab Undang-Undang Hukum Acara Pidana (KUHAP) dibedakan secara limitatif antara istilah "penyidik" atau Opsporing/ Interrogation dan Penyelidik. Dengan tegas Bab I Tentang Ketentuan Umum Pasal 1 angka 1 jo Pasal 6 ayat (1) Kitab Undang-Undang Hukum Acara Pidana (KUHAP), Bab I Pasal 1 angka 10 dan 11 Undang-Undang Nomor 2 Tahun 2002 disebutkan bahwa "penyidik" adalah pejabat polisi Negara Republik Indonesia atau Pegawai Negeri Sipil tertentu yang diberi wewenang khusus oleh undang-undang untuk melakukan penyidikan. Sedangkan mengenai pengertian Penyidikan diartikan sebagai "pemeriksaan permulaan oleh pejabat-pejabat yang untuk itu ditunjuk oleh undang-undang segera setelah mereka dengan jalan apapun mendengar kabar yang sekedar beralasan, bahwa ada terjadi sesuatu pelanggaran hukum. ${ }^{7}$

Sedangkan apabila kita mengacu kepada ketentuan Pasal 1 angka 2 Kitab Undang-Undang Hukum Acara Pidana (KUHAP) disebutkan bahwa Penyidikan ialah "Serangkaian tindakan penyidik untuk menemukan barang bukti dan untuk mengngka siapa tersangkanya". Sesuai konteks Pasal 1 angka 2 Kitab UndangUndnag Hukum Acara Pidana (KUHAP), dengan konkret dan faktual dimensi penyidikan tersebut dimuali ketika terjadinya tindak pidana sehingga melalui proses penyidikan hendaknya di perole keterangan tentang aspek-aspek sebagai berikut:

1. Delik yang dilakukan

2. Tempat tindak pidana dilakukan

3. Waktu tindak pidana dilakukan

4. Cara tindak pidana dilakukan

5. Dengan alat apa tindak pidana dilakukan

6. Laatar belakang tindak pidana dilakukan

7. Siapa pelakunya. ${ }^{8}$

Pemeriksaan dilakukan oleh penyidik jika peristiwa tersebut merupakan peristiwa pidana. Yang mana pertama sebelum di lakuaknnya penyidikan, harus ada tahap penyelidikan, disini penyelidik menentukan dulu apakah peristiwa ini peristiwa pidana atau tidak, jika peristiwa tersebut ternyata peristiwa pidana barulah dimuai penyidikan, disini penyidik akan mencari tersangka dan alat bukti tindak pidana yang dilakukan . Titik pangkat pemeriksaan di hadapan penyidik ialah tersangka. Dari dialah diperoleh keterangan mengenai peristiwa pidana yang sedang diperiksa.

Penipuan berasal dari kata tipu yang berarti mengakali orang lain untuk mendapatkan keuntungan. ${ }^{9}$ Sedangkan penipuan online adalah suatu perbuatan atau perkataan dengan maksed untuk menyesatkan dengan menggunakan layanan

${ }^{7}$ R. Tresna, Peradilan di Indonesia dari Abad Ke Abad, Sinar Grafika, Jakarta, 2006, hal. 72.

${ }^{8}$ R. Tresna, Op. Cit., hal.78.

${ }^{9}$ http:/bacaonline. Blogspot.com/2011/kayra-tulis-hukum-penipuan-melalui-html 
elektronik untuk melakuka suatu perbuatan atau menyakinkan seseorang untuk mempercayainya tentah itu tentang suatu informasi yang merugikan atau jual beli, untuk menguntungkan dirinya sendiri dengan melawan hak. ${ }^{10}$ Erbuatan yang dilakukan tersebut dapat dikenakan pidana, bedanya dengan tindak pidana konvensial tindak pidana penipuan melalui elektoronik di atur dalam undangundang khus yaitu Undang-Undang No 11 Tahun 2008 yang sudah di perbaharui denga Undang-Undang No 19 Tahun 2016 tentnag Informasi dan Transaksi Elektronik.

Bentuk perbuatan tindak pidana penipuan melalui media elektronik ini di atur di dalam Pasal 28 ayat (1) Undang-Undang No 11 Tahun 2008 sebagai mana yang sudah di perbaharui dengan Undang-Undang No 19 Tahun 2016 ayat (1) yang menyatakan: " setiap orang dengan sengaja tanpa pak menyebarkan berita bohong dan menyesatkan yang mengakibatkan kerugian konsumen dalam transaksi elektronik". Yang mana ketentun pidananya di atur di dalam Pasal 45 ayat (2) yang menyatakan "setiap orang yang memenui unsur Pasal 28 ayat (1) atau ayat (2) dipidana dengan pidana penjara paing lama 6 (enam) tahun dan/atau denda paling banyak Rp.1000.000.000,00 (satu miliar rupiah)".

Kejahatan dunia maya (cybercrime) merupakan tindak pidana criminal yang dilakukan melalui media elektronik sebagai sumber utamanya, kejatan ini merupakan kejahatan yang memanfaatkan kemajuan teknologi untuk melakukan tindak pidana. ${ }^{11}$ Kejahatan dunia maya (Cybercrime) di artikan sebagai perbuatan melanggar hukum yang memanfaaatkan kemajuan teknologi untuk melakukan kejahatan. ${ }^{12}$

\section{METODE PENELITIAN}

Penelitian ini menggunakan jenis penelitian empiris yang artinya penelitian ini mendeskripsikan fakta yang terjadi di lapangan dan mengtahui efektifitas hukum positif di masyarakat. Apakah hukum dimasyarakat itu sudah berjalan sesuai kaidah norma yang berlaku atau hanya sebagai formalitas. Dalam penelitian ini peneliti langsung mencari data ke Polresta jambi mengenai tindak pidana penipuan melalui media elektronik online, apakah tindak pidana tersebut diproses hingga selesai apa saja kendala penyidik Polresta jambi dalam mengungkap tindak pidana penipuan, melalui media elektronik di Polresta Jambi. ${ }^{13}$

Penelitian hukum mempunyai 3 (tiga) bentuk penelitian, antara lain penelitian diagnostik, penelitian preskriptif dan penelitian evaluatif." ${ }^{14}$ Berdasarkan ketiga bentuk

\footnotetext{
${ }^{10}$ https://id.m.wikipedia.org/20Januari 2020/html

${ }_{11}$ Josua Sitompul, Cyberspace, Cyberlaw: Tinjauan Aspek Hukum Pidana, Jakarta. Rajawali Pers. 2012, hlm.25.

${ }^{12}$ Niniek Suparni, Cyberspance Problematika \& Antisipasi Pengaturannya, Jakarta. Sinar Grafika, 2009, hlm. 25.

${ }^{13}$ Soerjono Soekanto, Pengantar Penelitian Hukum, UII Press, Jakarta 2001, Hal.51.

${ }^{14}$ Soerjono Soekamto, Op. Cit., Hal.8.
} 
penelitian tersebut penelitian yang dilakukan oleh tim penelitian mengenai proses dan kendala penyidik dalam mengungkap tindak pidana penipuan melaulai media elektronik ini adalah diagnostik dan prekriptif yang bertujuan untuk mengetahui kendala penyidik di Polresta dalam mengungkap tindak pedana penipuan melalui media elektronik.

Spesifikasi penelitian yang digunakan adalah bentuk Deskriptif yaitu mempaparkan proses dan kendala Penyidik Polresta Jambi dalam mengungkap Tindak Pidana Penipuan Melalui media Elektronik

Dalam kerangka pikir ini peneliti berusaha menggambarkan secara singkat proses pemecahan masalah yang dikemukakan dalam penelitian agar mempermudah dalam pemahaman penulis membahas selanjutnya, yaitu sebagai berikut:

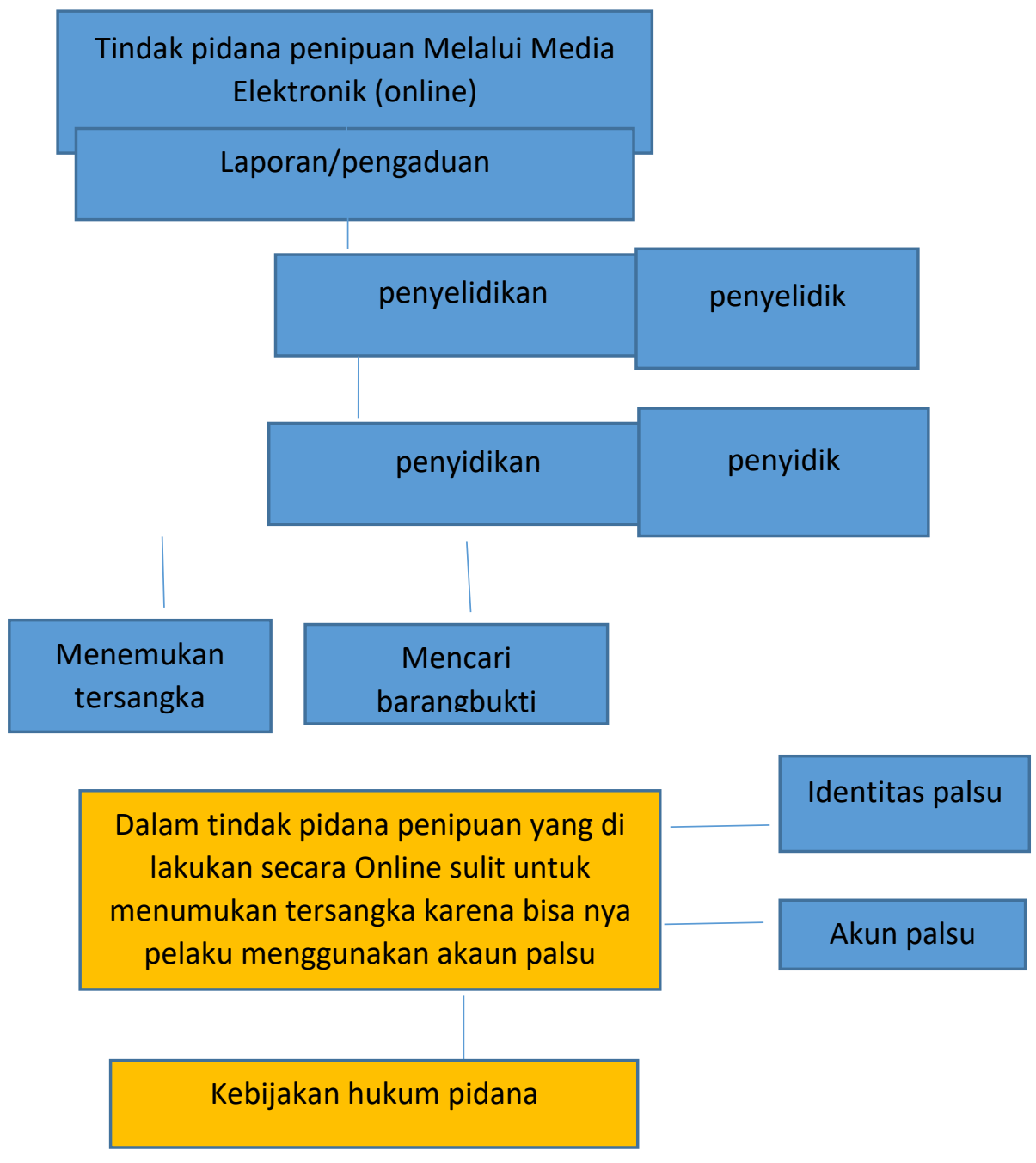




\section{PEMBAHASAN}

\section{Proses Penyidikan Penyidik Polresta Jambi dalam menangai Tindak Pidana Penipuan Melalui Media Elektronik.}

Proses penyidikan dimulai dengan adanya pemberitahuan di mulainya penyidikan dilakukan dengan SPDP (Surat Pemberitahuan di mulainya Penyidikan) sebagaimana di jelaskan oleh Penyidik Tipider Polserta Jambi sebagai berikut:

Dala hal SPDP ini secara umum harus melapirkan:

1. Laporan Polisi

2. Resume BAP Saksi

3. Resume BAP Tersangka

4. Berita Acara Penangkapan

5. Berita Acara Penahanan

6. Berita Acara Penggeledahan

7. Berita Acara Penyitaan

Lebih lanjut dijelaskan Penyidik Unit Tepider Ibda Junardi bahwa Proses penyidikan dimulai setelah diketahui atau diduga telah terjadi suatu Tindak pidana berdasarkan laporan, pengaduan serta informasi dari masyarakat baik laporan ataupun pengaduan serta informasi dari masyarakat yang diterima penyelidik atau penyidik merupakan bahan yang masih mentah dan perlu diadakan penelitian dan penyaringan, setelah laporan diterima, petugas polisi segera mengambil tindakan yaitu dengan mendatangi tempat kejadian perkaara (TKP) tindakan tersebut dialkukan untuk mencari keterangan-keterangan dan bukti guna menentukan suatu peristiwa yang dilaporkan tersebut merupakan tindak pidana atau bukan tindak pidana, melengkapai keterangan dan bukti-bukti yang diperoleh agar menjadi jelas sebelum dilakukan tindakan selanjutnya dan juga sebagai persiapan pelaksanaan penindakan atau pemeriksaan. Setiap peristiwa yang dilaporkan dan diadukan kepada pihak kepolisian atau penyidikan belum pasti tindak pidana, untuk itu perlu dilakukan proses penyelidikan yang menentukan apakah peristiwa tersebut merupakan tindak pidana atau bukan, apabila merupakan tindak pidana, penyidik sesuai dengan kewajibanya memiliki kewenangan untuk melakukan tindakan penyidikan yang sebagaimana telah diatur dalam KUHAP, untuk memulai penyidikan tindak pidana maka dikelurkan Surat Perintah Di mulainya Penyidikan (SPDP). Setelah diterbitkannya surat perintah tersebut penyidik berhak melakukan tindakan-tindakan hukum terhadap orng maupun benda atau barang yang ada hubungannya dengan tindak pidana yang terjadi. Tindakan pertama yang dilakukan adalah penangkapan, tahap penangkapan ini berguna untuk memperlancar proses pelaksanaan penyidikan yang di duga keras melakukan tindak pidana. Setelah penangkapan dilakukan segera dilakukan pemeriksaan untuk engetahui perlu dilakukan suatu penahanan, penahanan dilakukan dengan pertimbangan bahwa 
tersangka dikhuatirkan akan melarikan diri,, merusak dan menghilangkan barang bukti dann mengulani lagi tindak pidana yang telah dilakukanya, setelah melakukan penahan dilakukanlah tahapan pemeriksaan tahapan ini berguna untuk mendapatkan keterangan ataupun kejelasan tersangka atau saksi dan barang bukti maupun unsur-unsur tindak pidana yang telah terjadi untuk di tulis ke dalam berita acara pemeriksaan (BAP) Tersangka. Setelah tahap pemeriksaan dilakukan tahap penggeledahan dapat dilakukan apabila semua unsur sudah lengkap dan surat izin penggeledahan dikeluarkan, setelah penggeledahan dilakukan penyitaan, penyitaan dilakukan apabila sudah dilengkapi dengan surat izin. Barang yang boleh di sita antra lain:

1. Benda atau tagihan bila seluruh atau sebagaian diduga diperoleh adari tindak pidana atau sebagaian dari hasil dari tindak pidana

2. Benda yang digunakan langsung untuk melakukan tindak pidana atau untuk mempersiapkannya

3. Benda-benda yang digunakan untuk menghalangi-halangi penyidikan suatu tindak pidana.

Apabila semua tahapan ini sudah selesai maka penyidik wajib segera menyerahkan berkas perkara kepada penuntut umum. ${ }^{15}$

Pada dasarnya penipuan online sama dengan penipuan konvensional biasa yang menjadi pebedaan hanya pada saraan perbuatannya yakni menggunakan system elektronik, (komputer, internet, perangkat telekomunikasi). Begitu juga dalam hal proses penyidikanya, tetap erpedoman pada KUHAP (Kitab Undang-Undang Hukum Acara Pidana).

Lebih lanjut dijelaskan Penyidik Unit Tipider Brigpol Dendy Krisandi:

Proses Penyidikan Tindak Pidana Penipuan Online ini sama dengan adanya laporan dari si terlapor ke pada pihak kepolisian setelah adanya laporan tersebut diproses dalam tahap penyelidikan terlebih dahulu apabila telah memenuhi unsur ada bukti saksi dan unsur-unsur dalam undang-undang barulah dilakukan proses sidik setelah proses sidik dirasa sudah lengkap baru dikirimmkan berkas tahap 1 ke kejaksaan. ${ }^{16}$.

\section{Kendala dan upaya penyidik dalam menganggulangai Tindak Pidana Penipuan Melalui Medi Elektronik}

Tindak Pidana Penipuan melalui media elektronik marak terjadi di kota Jambi selama 3 (tiga) tahun terakhir ini pada tahuun 2017 jumlah laporan yang di terima Polresta Jambi 4 sementara yang terselesaikan 3, di tahun 2018 ada 7 laporan dan yang terselesaikan ada 4 laporan dan di tahun 2019 ada 14 alporan hanya yang terselesaikan ada 7 laporan. Berdasarkan data di atas banyak laporan yang tidak dapat terselesaikandinkarenakan penyidik kesulitan dalam mengungkap kasus penipuan

\footnotetext{
${ }^{15}$ Wawancara, Ibda Junardi, Penyidik Unit Tipider Polrestta Jambi, tanggal 12 Juni 2020.

${ }^{16}$ Wawancara, Brigpol Dendy Krisanto, Penyidik Unit Tipider Polresta Jambi, tanggal 12 Juni 2020.
} 
melalui media elektronik. Hal tersebut karena adanya beberapa kendala yang dialami Penyidik Polresta Jambi.

Berikut adalah kendala-kendala penyidik dalam mengungkap kasus-kasus penipuan online khususnya cybercrime di Polresta Jambi diantaranya meliputi:

1. Sulitnya melacak pelau kejahatan penipuan online dikarenakan pelaku biasanya akan menggunakan identitas yang palsu atau juga meminjam identitas orang lain mulai dari nomor telepon yang di registrasi identitasnya dipalsukan, nomor rekeningnya bisa saja menggunakan nomor rekening orang lain dan sarana dan prasarana lainya yang digunakan pelaku untuk memalsukan kejahtannya. Penyidik Unit Tipider Bripka Prasetio Utomo, menjelaskan: Pada laporan tindak pidana penipuan melalui media elektronik yang telah kami proses kesulitan menacar pelaku ini disebabkan karena pelaku dan korban tidak saling bertemu satu sama lain dan biasanya pelaku juga membunjuk korban agar tertarik membeli suatu produk yang ditawarkan suapaya membayarkan sejumlah uang muka di terima melalui ytansfer ewat perbankan. ${ }^{17}$

2. Sulitnya membuka rekening pelaku karena perjanjian birokrasi bank. Pihak bank tidak akan mudah membuka rekening pelaku karena perjanjian birokrasi bank. Lembaga bank adalah "badan usaha yang menghimpun dana dari masyarakat dalam bentuk simpanan dan menyalirkan kepada masyarakat dalam bentuk kredit dan bentuk-bentuk lainya dalam rangka meningkatkan taraf hidup rakyat banyak" ( Pasal 1 angka 2 UU No 10 Tahun 1998). Tentunya mempunyai aturan berupa rahasia bank dimana rahasia bank berdasarkan (Pasal 1 angka 28 UU No 10 Tahun 1998 tentang Perbankan) " segala sesuatu yang berhungan dengan keterangan mengenai nasabah penyimpanan san simpananya, nasabah sebagai pemilik rekening bank mempunyai hak untuk di lindungi identitasnya di mana dapat diartikan tidak sembarangan orang dapat mengetahui identitas dari setiap pemilik rekening bank tersebut.

3. Belum adanya Unit yang khusus menangani kausu-kasus kejahatan cybercrime Saaat ini unit yang khusus menangani kasus kejahatan cybercrime hanya unit Tipider (Tipider Tindak Pidana Tertentu) yang berjumlah 15 (Limas Belas) personil, tentunya yang menangai kejahatan cybercrime ini sebagaia besar bukan penyidik khusus yang mengettri bidang ITE. Penyidik Unit Tipider Bripka Prasetio Utomo Menjelaskan: Penyidik Polresta Jambi diunit Tipider ini memang merangkap tugasnya selain melakukan pennganan terhadap penipuan online juga menangani tindak pidana tertentu lainya seperti: Fedusi, HAKI, pemalsusan merek dagang, perjudian dan kejahatan cybercrime lainya. Sehingga sulit bagi penydik untuk focus medalami kasus ctbercrime ini. ${ }^{18}$

\footnotetext{
${ }^{17}$ Wawancara, Bripka Prasetio Utomo, Penyidik Unit Tipider Polresta Jambi, tanggal 12 Juni 2020.

${ }^{18}$ Wawancara, Bripka Prasetio Utomo, Penyidik Unit Tipider Polresta Jambi, Tanggal 12 Juni 2020.
} 
4. Minimalnya Penyidik Polresta Jambi yang memiliki kemampuan dan pengalaman dalam bidang ITE. Hal ini dikarenakan keterbatasan jumlah penyidik Polresta Jambi dalam menangani kasus Cybercrimr sehingga penyidik tidak maksimal dalam menangani kejahatan ini. Polresta Jambi juga melakukan kerjasama langsung dengan Polda Jambi merekap kasus-kasus apa saja yang belum selesai dan kemudian memberikan keseluruhan laporan Polresta Jmabi ke Polda Jambi untuk ditindak lanjuti. Penyidik Unit Tipider Bripka Ibda Junardi menjelaskan Memang ada kerja sama dengan personil Penyidik dari Polda Jambi, namun meskipun ada bantuan tatap saja hal ini kuga tidak bayak membantu dikarenakan penyidik sulit untik medeteksi keberadaan pelaku karena identitas pelaku yang palsu atau pelaku menggunakan identitas orang lain dan pelaku enggan melakukan transasi secaccra bertatap muka. ${ }^{19}$

5. Keterbatasan alat-alat khusus cybercrime yang dimiliki oleh Penyidik Polresta Jambi. Keterbatasan alat-alat moderen di Polresta Jambi menyebabkan waktu cukup lama dalam mengungkap tindak pidana penipuan online dan alat-alat yang dibutuhkan. Bripka Ibda Junardi mengatakan "penyidik tidak bisa memberitahukan alat-alat khusus yang digunakan karena ini bersifat rahasia". ${ }^{20}$

Dikarenakan alat-alat khusus cybercrime yang kurang pihak penyidik tetap memiliki cara lain selain menggunakan alat-alat tersebut, yaitu:

Penyidik Unit Tipeder Bripka Ibda Junardi menjelaskan:

1. Kerja sama pihak Polresta Jambi dengan pihak bank. Hal ini sangat penting, sebab pelaku sering menggunakan sarana perbankkan dalam bertansaksi. Namun dalam kenyataannya penyidik mengalami kesulitan dalam hal ini, do karenakan pihak bank tidak bisa memberikan informasi tentang identitas nomor rekening pelaku kepada Polisi tanpa seijin Gubernur Bank Indonesia.

2. Kerja sama pihak Polresta Jambi dengan penyedian layan operator seluler ataupun internet service provider. Kejahatan cyebercriem menggunakan media internet yang pasti memiliki IP addres (internet provider addres), tersimpan dalam server pengelola website/homepage yang dijadikan sarana pelaku dalam melakukan penipuan. Meskipun penyidik tela berhasil melacak sebuah IP addres. Pada intinya kembali lagi pada identitas pelaku kejatan yang palsu

3. Kerjasama antara Polresta Jambi dengan Masyarakat Citra lembaga kepolisian sekarang ini kurang baik dimata masyakat.sehingga masyakat kurang begitu mempercayai kinerja penegak hukum. ${ }^{21}$

Namun yang paling menjadi kendala Penyidik Polresta Jambi dalam mengungkap Tindak Pidana Penipuan Melalui Media Elektronik yaitu: sulitnya membuka rekening bank pelaku karena adanya perjanjian birokrasi bank, untuk izin melakukan pelacakan terhadap rekening bank ini memakan waktu yang sangat lama

\footnotetext{
${ }^{19}$ Wawancara, Bripka Ibda Junardi, Penydidk Tipider Polresta Jambi, Tanggal 12 Juni 2020

${ }^{20}$ Ibid

${ }^{21} \mathrm{I}$ bid
} 
karena pihak Polresta harus meminta izin dulu kepada Polda Jambi dan Polda mengirimkan izin ke POLRI dan POLRI membuat suarat kepada Bank Indonesia, dan baru bank Indonesia menunjuk kepada bank terkait untuk membuka rekening yang ingin diselidiki, proses inilah memakan waktu yang sangat lama sehingga Penyidik sulit mengungkap kasus tindak pidana penipuan melalui media elektronik ini.

Selain itu penulis juga berupaya mencari tau alasan mengapa korban mau melakukan pembelian online ataupun melakukan transaksi melalui media elektronik, dari beberapa korban penulis menemui korban yang bernama Ifan warga talang banjar dari keterangan ifan di mejelaskan alasan mau melakukan pembelian melalui media elktronik karena harganya murah di bandingkan dengan harga di toko. Selain itu Yayan warga pematang sulur yang juga pernah menjadi korban penipuan melalui media elektronik yaya menjelaskan alasan mau melakukan pembelian melalui media elektronik karena barang yang di cari sudah langka, kemudian ada di jual di media sosial sehingga ia tertarik untuk melakukan pembelianmisalnya saat terjadi pandemi covid 19 tahun ini, sempat masker dan hand sanitizer putus, kemudian di media sosial Ig ada yang menjual barang tersebut namun setelah uang di transper namun barang tidak kunjung datang.

Dalam menangani Tindak Pidana Penipuan melalui media elektronik ada bebarapa upaya yang harus dilakukan pihak penyidik Polresta Jambi dalam meminimalisir kendala-kendala yang sudah di jelaskan tadi, dari kendala-kendala tersebut inilah upaya yang dilakukan pihak Penyidik Polresta Jambi untuk mengungkap Tindak Pidana Penipuan melalui media elektronik di Kota Jambi, berikut adalah upaya dalam menanggulangani tindak pidana penipuan melalui media elektronik:

\section{Upaya Preventif (pencegahan)}

1. Memberikan penyuluhan dan himbawan kepada masyarakat agar berhati-hati dalam melakukan transaksi jual beli melalui media elektronik, memberikan arahan agar lebih cermat dalam melakukan jual beli tanpa bertemu langsung dengan pembelinya, serta memberikan arahan bahwa jangan langsung percaya dalam memberikan nomor rekening kepada orang lain maupun mentrasfer uang kepada orang lain dengan dalil orang tersebut mengakatan bahwa ada keluarga kita yang kecelakaan sehingga memerlukan biaya untuk kerumah sakit, initinya harus cermat dan hati-hati ketika tiba-tiba ada telpon yang pada inti pembicaraan meminta kita mentrasfer uang.

2. Membuat unit Kusus Cybercrime. Katim Penyidik Unit Tipider Polresta Jambi mengatakan " kita telah mengupayakan mencanangkan dana untuk mendirikan unit Cybercrime akan tetapi belum terlaksana sampai sekarang sebeb untuk mendirika suatu unit dibutuhkan biaya yang sangat banyak. ${ }^{22}$ Karena unit memuat alat-alat canggih dan laboratorium khusus untuk dapat mendeteksi

\footnotetext{
${ }^{22}$ Wawancara, Bripka Teguh Santiko, Penyidik Unit Tipider Polresta Jambi tnggal 12 Juni 2020.
} 
kejahatan-kejahatan berkaitan dengan ITE. Polresta Jambi akan terus mengupayakan untuk mendirikan unit cybercrime, agar penanganan kasusnya lebih fokus.

\section{Upaya Respresif (upaya Penanggulangan)}

1. Memblokir rekening pelaku kejahatan penipuan melakuki media elektronik yang berkoordinasi dengan pihak bank. Hanya sebatas kerjasama pemblokiran sajlah yang dibisa diupayakan penyidik Polresta Jambi untuk menanggulangi kejahatan. Katim Penyidik Unit Tipider Polresta Jambi menjelaskan:

2. Akan lebih membantu lagi jika dibuatkan MOU kerja sama POLRI dan Bank Indonesia MOU sendiri merupakan sebuah dokumen legal yang menjelaskan persetujuan antara dua belah pihak. Sehingga diharapkan dengan adanya MOU antara POLRI dengan seluruh instansi perbankan yang ada di Indonesia saling bekerjasama dan penyidik bisa mengembangkan kasus-kasus cybercrime tanpa terhalang oleh birokrasi-birokrasi yang menghambat penyidik dalam melakukan penyelidikan dan penyidikan terhadap pelaku kejahatan penipuan online melalui instansi perbankan jadi tidak hanya sebatas pemblokiran nomor rekening saja. ${ }^{23}$

3. Memberikan pelatihan dan pendidikan kepada setiap penyidik Polresta Jambi tentang masalah penanganan terhadap kasus tindak pidana penipuan melalui media elektronik.

4. Penyidik Unit Tipider menjelaskan:

5. Karena kejahatan ini mempergunakan sistem jaringan computer, sehingga pihak kami mengirimkan beberapa personil 3 sampai 5 personil untuk mendapat pelatihan guna memperoleh pendidikan tentang ITE di Polda Jmabi dan Mabes Polri diharapkan para personel tersebut pulang mendapatkan ilmu yang bsa digunakan untk menangani kasus ini. ${ }^{24}$

6. Meningkatkan kerja sama antar lembaga baik dengan Bank dan Operator seluler Internet Service Provider.

Maka dari itu penyidik berupaya menanggulangani dengan cara:

1) Meningkatkan kerjsama anta lembaga bank secara bilateral dalam upaya penanganan cybercrime, antara lain melalui perjanjian yang telah ditentukan oleh kedua belah pihak.

2) Meningkatkan kerjasama dengan operator seluler atau internet service provider dan tidak membatasi penyidik dalam membuka identitas pelaku. Memberikan asaran kepada penyedia layanan operasional seluler dan internet untuk meningkatkan sistem pengamanan jaringan computer nasional sesuai standar nasional.

3) Meningkatkan kinerja Polri untuk lebih mengayomi masyarakat, meningkatkan penyuluhan dan beberapa aktife membina masyarakat tentang

\footnotetext{
${ }^{23}$ Ibid

${ }^{24}$ Wawancara. Bripka Joni Heryanto, Penyidik Tipider Polresta Jambi tanggal 12 juni 2020.
} 
pengetahuan kejatan konvensional maupun kejahatan model baru, serta peningnya mencegah kejahatan tersebut terjadi lagi

\section{KESIMPULAN DAN SARAN}

\section{Kesimpulan}

1. Proses Penyidikan Tindak Pidana Penipuan Online melalui Media Elektronik, dalam proses penyidikan tidak ada perbedan antara proses penyidikan tindak pidana biasa dengan tindak pidana penipuan melalui media elektronik

2. Kendala yang di alami Penyidik yaitu sulinya melacak pelaku biasanya akan menggunakan identitas yang palsu, sulitnya membuka rekening pelaku karena ada perjanjian birokrasi bank, belum adanya unit khusus menangai kasus-kasus kejahatan cybercrime di Polresta dan minimnya Penyidik Polresta Jambi yang memiliki kemampuan dan pengalaman dibidang ITE atau cybercrime

\section{Saran}

1. Pihak kepolisian perlu meningkatkan kinerja dalam mengungkap tindak pidana penipuan melalui media elektronik baik secara preventif dan responsif yang di dukung dengan pemberdayaan sumber daya manusia terutama kepada personel kepolisian untuk diberikan pembekalan mengenai ilmu cyebr yang di dukung dengan sarana prasarana yang memadai dibidang teknologi agar dapat secara tugas menangani kasus cybercrime.

2. Masyarakat diharapkan berhati-hati dalam melakukan transaksi jual beli teutama dalam jual beli melalui via internet atau online, jangan mudah tertipu dengan barang murah yang harganya jauh dari pasaran. Jangan langsung percaya jika ada orang yang menghubungi lalu meminta transper uang dengan dalil keluarga kita kecelakaan, cek benar apakah memang benar atau hanya sekedar tipu muslihat pelaku agar mendapatkan uang korban.

\section{DAFTAR PUSTAKA}

\section{Buku}

Andi Hamzah. Hukum Acara Pidana Indonesia, Sinar Gfarika, Jakarta, 2017

Adami Chazawi, Tindak Pidana Informasi \& Transaksi Elektronik, Media Nusa Creatife, Malang, 2015.

Abdul Wahid, Kejahatan Mayantara, PT Refika Aditama, Bandung, 2005.

Andi Hamzah. Hukum Pidana yang Berkaitan Dengan Komputer, Jakarta, Sinar Grafika, 1996.

Budi Suhuryanto, Tindak Pidana Teknologi Informasi (Cybercrime), Urgensi Pengaturan dan Celah Hukumnya, Jakarta. Rajawali Pers, 2012 
Josua Sitompul, Cyberspence Tinjauan Aspek Hukum Pidana, Rajawali Pers, Jakarta, 2012.

Niniek Suparni, Cyberspance Problematika \& Anyisipasi Pengaturannya, Sinar Grafika, Jakarta, 2009.

R.Tresna, Peradilan di Indonesia Dari Abad Keabad, Sinar Grafika, Jakarta, 2006.

Wirdjono Prodjodikoro, Tindak Pidana Tertentu di Indonesia, Bandung, Refika Aditama. 2018

\section{Peraturan Perundng-Undangan}

Republik Indonesia. Peraturan Pemerintah Pelaksanaan Kitab Undang-Undang Acara Pidana. PP Nomor 27 Tahun 1983

Republik Indonesia. Undang-Undang Tentang Informasi Transaksi Elektronik. UU Nomor 11 Tahun 2008 yang sudah di perbaharui dengan UU Nomor 19 Tahun 2016

Republik Indonesia. Undang-Undang Tentang Perbankan UU Nomor 10 Tahun 1998. 